VERSITA

Review

DOI: 10.2478/rrlm-2013-0013

\title{
What about microparticles? Perspectives and practical aspects
}

\section{Microparticulele. Perspective şi aspecte practice}

\author{
Andra Costache ${ }^{1 *}$, Simona I. Avram ${ }^{2}$, Alina Cernucan ${ }^{3}$, Doina Barbu ${ }^{4}$, \\ Silvana Angelescu ${ }^{1,4}$, Delia Mut Popescu ${ }^{4}$, Anca R. Lupu ${ }^{1,4}$ \\ 1. "Carol Davila" University of Medicine and Pharmacy \\ 2. "Regina Maria" Clinical Laboratory Division - Hemostasis Department \\ 3. "Medcenter" Central Laboratory - Center for Excellence in Laboratory Medicine and Pathology \\ 4. "Coltea” Clinical Hospital, Hematology Department
}

\begin{abstract}
The first description of microparticles dates back to 1967, when Wolf reported platelet membrane fragments in human plasma and called them "platelet dust". These vesicles were later called microparticles and the knowledge about their characterization and function has advanced since then. The generation of microparticles represents a mechanism of intercellular communication, playing various roles in both physiological and pathological conditions. Besides other multiple roles in pathology such as inflammation, atherogenesis and cancer spreading, platelet-derived microparticles are involved in thrombogenesis. Tissue factor and phosphatidylserine are both exposed on the outer membrane of platelet-derived microparticles, providing catalytic procoagulant surfaces. The evaluation of microparticles may represent a possible investigation and diagnostic tool. Their enumeration and characterization is challenging and flow cytometry remains the most widely used method for the analysis of microparticles. The aim of the authors is to review the most relevant information on the main properties, mechanisms of generation, and clinical relevance of platelet-derived microparticles, since their evaluation is increasingly considered as a diagnostic biomarker.
\end{abstract}

Keywords: microparticles, haemostasis, flow cytometry

\section{Rezumat}

Prima descriere a microparticulelor datează din 1967, când Wolf a comunicat prezența fragmentelor membranare trombocitare în plasma umană, numindu-le "praf plachetar". Aceste vezicule au fost ulterior denumite microparticule, iar cunoştințele despre caracterizarea şi funcția lor au avansat de atunci. Generarea de microparticule reprezintă un mecanism de comunicare intercelulară, având diferite roluri, atât în statusul fiziologic, cât şi în diverse afecțiuni. În afară de participarea lor în patogenia unor procese precum inflamația, aterogeneza sau metastazarea neoplaziilor, microparticulele trombocitare sunt implicate în trombogeneză. Factorul tisular şi fosfatidilserina sunt ambele expuse pe membrana externă a microparticulelor trombocitare,

*Corresponding author: Andra Costache, Spitalul Clinic Coltea, Hematologie - Laborator,

B-dul I.C. Bratianu Nr.1, Sector 3, Bucuresti. E-mail: andracostache@gmail.com 
oferind suprafețe catalitice procoagulante. Evaluarea microparticulelor constituie un potențial instrument de investigare şi diagnostic. Enumerarea şi caracterizarea lor reprezintă o provocare, iar metoda de analiză cea mai utilizată este citometria în flux. Având în vedere tendința actuală de a considera microparticulele ca fiind un adevărat marker de diagnostic, autorii îşi propun să prezinte o imagine de ansamblu asupra celor mai relevante informații $\mathrm{cu}$ privire la proprietățile principale, mecanismele de producție şi importanța clinică a microparticulelor trombocitare.

Cuvinte cheie: microparticule, hemostază, citometrie în flux

Received: $6^{\text {th }}$ December 2012; Accepted: 10 $0^{\text {th }}$ February 2013; Published: $22^{\text {nd }}$ February 2013.

\section{Introduction}

Microparticles (MPs) represent submicron sized vesicles released from the surface of activated or apoptotic cells as a result of membrane remodeling (1). All cell types shed MPs, therefore they are present in various body fluids such as plasma, synovial fluid, and urine (2).

MPs constituents include cell-surface receptors, cytosolic proteins, DNA, mRNA, and micro RNA derived from their cell of origin. The size of microparticles ranges between 0.1 and 1 micrometer and the phospholipid and protein content depends on the type and state of the parental cell. This high heterogeneity in dimensions and composition distinguishes clearly the MPs from exosomes, which are smaller in size and more homogenous in composition and act as conveyors of immune responses (3).

Besides the surface proteins and the cytoplasmic components emerged from the parental cells, microparticles are able to acquire proteins from other cell types through a fusion process between MPs and the membrane of a different cell (4).

Microparticles shed from different cell types including leukocytes, platelets, erythrocytes, endothelial cells, and various cancer cells have been identified in the circulating blood.

Furthermore, syncytiotrophoblast derived microparticles were found into maternal circulation during pregnancy. (5)

\section{MPs roles}

According to Nieuwland and Sturk (6), the roles of microparticles have been reported to fall into the following three categories: intercellular communication, MPs being able to transfer specific parental cell receptors to the surface of other cells (e.g.. tissue factor (TF) transfer from the surface of leukocyte-derived microparticles to the surface of activated platelets (4); protection, enabling cells to discard toxic metabolites or noxious modified cellular components (e.g.. chemotherapeutics, oxidized phospholipids, caspase 3); intercellular exchange of genetic information due to mRNA, microRNAs and DNA content (the uptake of tumor derived microparticles containing microRNA may modify gene expression in host cells) $(7,8)$.

Therefore, MPs from various cells are implicated both in physiological and pathological conditions. Recent reports suggest that MPs can regulate inflammation, stimulate coagulation, affect vascular functions, can also play a role in immuno-modulation, stem cell engraftment, angiogenesis, cell proliferation or differentiation, and tumor metastasis (9-14). Moreover, MPs are incriminated in spreading of infective virus (HIV) and prions to target cells (15).

Some publications indicate that MPs differ in concentration, composition and function in various diseases compared to healthy subjects, consequently they could represent important biomarkers.

\section{Platelet derived Microparticles (PMPs)}

Described for the first time 45 years ago (16), PMPs represent the majority of the pool of circulating microparticles, constituting between $70 \%$ and $90 \%$ of the total number of 
MPs, whereas less than $10 \%$ originate from granulocytes and less than 5\% from endothelial cells, red blood cells and monocytes (17).

\section{PMPs formation}

PMPs are continuously formed in the circulation through an active and highly organized process triggered by platelet activation or apoptosis, involving cytoskeletal reorganization and distinct domains of the cell membrane shedding $(18,19)$.

In "resting" cells each of the two leaflets of the plasma membrane bilayer has a specific lipid composition: the inner leaflet contains primarily phosphatidylserine (PS) and phosphatidylethanolamine (PE), whereas the external leaflet is rich in phosphatidylcholine and sphingomyelin. This asymmetric distribution is essential for the membrane function and is under the control of a complex transmembrane enzymatic balance that involves: gelsolin (present only in platelets, involved in the cleavage of the actin capping proteins), a flippase (an inward directed pump specific for PS and PE), a floppase (an outward directed pump), a lipid scramblase (which promotes bidirectional translocation across the bilayer), and calpain (hydrolyzes actin-binding proteins inducing the cleavage of cytoskeletal filaments).

Cellular activation or apoptosis induces subsequent increase of calcium concentration in the cytosol, followed by calcium-dependent activation of scramblase and floppase and inhibition of flippase activity, determining the loss of phospholipid asymmetry with the exposure of PS on the outer cell surface. Activation of calpain facilitate MPs shedding by cleaving cytoskeletal filaments. As a result blebbing (outward protrusion) and shedding of membrane MPs into circulating blood occur $(20,21)$.

A second physiologic source for circulating CD41+ MPs represented by megakaryocytes has been proposed by Flaumenhaft et al. Megakaryocyte-derived microparticles form as beads along the length of slender, unbranched micropodia and also form from continuous blebbing of the megakaryocyte surface. Unlike platelet-derived microparticles, they contain full length filamin A and do not express CD62P or lysosome-associated membrane protein-1 (LAMP-1). The degraded filamin A from PMPs represents a marker of cytoskeletal degradation, while CD 62P and LAMP-1 are markers of granule fusion (22).

\section{PMPs clearance}

The mechanism of clearance of PMPs from the circulation is not well understood. Recent evidence indicates the role of developmental endothelial locus-1(Del-1) as a mediator of clearance of PS expressing PMPs by the endothelium. Del-1, a 52-kDa glycoprotein secreted by endothelial cells acts as a bridging molecule between endothelial cells and PS-containing microparticles. For homeostatic reasons, additional PS-dependent clearance mechanisms must certainly exist (23).

\section{PMPs properties}

PMPs express various antigens including GP IX (CD42a), GPIb (CD42b), GPIIb/IIIa (CD41/CD61), TF, platelet activation dependent P-Selectin and contain various cytosolic proteins, mRNA, microRNA, depending on the triggering stimulus. Through the transfer of functional receptors or other compounds from the platelet, PMPs are able to amplify certain functions of the cells exposed to them.

Increasingly evidence shows that PMPs play important roles in blood coagulation, inflammation, atherogenesis, angiogenesis and cancer metastasis $(2,24-27)$.

\section{PMPs in hemostasis}

The central role of PMPs in hemostasis and coagulation is illustrated on the one hand by the bleeding syndromes associated with decreased number of microparticles in patients with Scott's and Castaman's syndromes (due to a defect in 
MPs production) and on the other by the high levels found in thrombotic diseases (28-30).

Although some were reported to carry anticoagulant proteins (thrombomodulin, TFPI, Protein C), PMPs are generally considered to be procoagulant and are believed to be key players in thrombus formation $(31,32)$.

Their procoagulant function relies on the expression of phosphatidylserine (PS) and on the presence of TF on the outer surface of their membrane, which are the main initiators of the coagulation cascade (33). As a result, the microparticle surface possesses approximately 50 - to 100 -fold higher procoagulant activity than the platelet surface (34).

PS is a negatively-charged aminophospholipid. In the vascular territory, exposed PS serves as a "catalytic template" enabling the assembly of the tenase and prothrombinase complexes and thrombin generation, thus promoting in situ hemostasis (20). This procoagulant role is enhanced by the capacity of PS to activate TF (35). In addition to these procoagulant features, PS represents a critical ligand for MPs clearance (36).

$\mathrm{TF}$, a transmembrane glycoprotein belonging to the cytokine receptor class II family, represent a key player in the initiation of blood coagulation, being the main trigger of the coagulation cascade $(37,38)$. MPs constitute the main pool of blood-borne TF, which could be either in "encrypted" form without coagulant activity or in "de-encrypted" active form $(15,18)$. MPs express TF at different degree and with different characteristics under physiological and pathological conditions (39). The role of TF-bearing MPs as biomarker in prethrombotic states prediction and diagnosis is under evaluation (40-42).

\section{Why MPs evaluation is needed?}

The screening tests in hemostasis evaluate the coagulation according to the classic cascade model. The paradigm shift to the "cell based" model of coagulation requires that the hemostasis evaluation should consider also cells and microparticles $(43,44)$.
Furthermore, there is a discrepancy between the results of screening tests and the bleeding or thrombotic complications of patients and the prediction of these complications is difficult because of the lack of laboratory markers.

\section{Methods of MPs analysis}

Because of their small size and heterogeneity, MPs detection and quantification is a difficult task. MPs analysis can be performed through various methods including flow cytometry, dynamic light scattering, atomic force microscopy, electron microscopy and new techniques such as impedance-based flow cytometry and nanoparticle tracking analysis (45). In addition, the procoagulant activity of MPs, can be evaluated using different functional assays. Each method has advantages and disadvantages: flow cytometry allows enumeration and determination of the cell origin but with a high level of variability, dynamic light scattering is efficient in size determining and quantification but unable to offer information on the properties of MPs, while atomic force microscopy and electron microscopy permit precise estimation of size and shape but have limitations due to the insufficiency of available equipment, routine analysis being excluded $(46,47)$.

\section{Flow cytometric analysis of MPs}

Flow cytometry remains the most widely used method for MPs analysis in clinical samples, although their enumeration and characterization is challenging. The small size of MPs places them at the limit of detection of flow cytometry devices, which is determined by the wavelength of laser light. Therefore, conventional flow cytometry detects only the MPs larger than $0.5 \mu \mathrm{m}(48)$.

MPs are sensitive to pre-analytical procedures including blood sampling, type of collection tube, transportation, time before processing, centrifugation steps and long term stor- 
age conditions. Cells can be easily activated during these steps, minor protocol changes leading to significant differences in MPs levels. According to Lacroix et al., there are three major preanalytical sources of variability: agitation of the tubes during transportation, the delay before first centrifugation and the protocol of centrifugation. Blood collection should be done on plastic-citrated tubes, using large size needles, without applying venostasis and discarding the first milliliters of blood. It is recommended to transport the sample tubes in vertical position, avoiding agitation. Samples should be processed optimal in the first hour postdrawing, but an interval of 2 hours between blood sampling and the first centrifugation is acceptable. Serial centrifugation is performed in order to obtain platelet free plasma, which will be stored at $-80{ }^{\circ} \mathrm{C}(49-51)$.

A working definition proposed by Robert S. et al. for flow cytometric determination of MPs includes: events that are $<1 \mu \mathrm{m}$ in size, express phosphatidylserine (PS), which is usually detected by binding of labeled AnnexinV, express antigens that characterize the cell of origin (e.g. CD41 for PMPs), and may be obtained by high speed centrifugation of platelet-poor plasma to deplete small platelets and cell debris (52).

Recent studies suggest two possible causes for unspecific antibody binding: one is the existence of $\mathrm{Fc}$ receptors on microparticles and the other is represented by the insoluble complexes, which appear to have overlapping biophysical properties (53-55).

The analytical phase is also a source of variability, due to differences in instrument settings and resolution (56). In an attempt to standardize these settings and to determine the MPs analysis region a blend of fluorescent beads of three diameters $(0.5,0.9$ and $3 \mu \mathrm{m})$ in a fixed numerical ratio (Megamix, Biocytex, Marseille) was created. Fine optical adjustments and both fluidics and optics cleanness are essential for a good resolution between background noise and microparticles.

In response to the heterogeneity of protocols which leads to difficulties in data comparison, the Scientific Standardization Committee of the International Society on Thrombosis and Haemostasis is in the process of developing guidelines to standardize the evaluation of microparticles (57).

\section{Conclusions}

In recent years, the study of microparticles has received increasing interest and some progress has been made in understanding their multiple roles. Platelet-derived microparticles may possess diagnostic significance as biomarkers in hypercoagulable state, constituting a possible hemostasis parameter. However, the flow cytometric evaluation of MPs needs urgent standardization in order to obtain reliable and reproducible results.

Also, further research should be directed to the development of pharmacological agent targeting MPs production.

\section{Conflicts of interests}

The authors state that they have no conflict of interest.

\section{References}

1. Diamant M, Tushuizen ME, Sturk A, Nieuwland R. Cellular microparticles: new players in the field of vascular disease? Eur J Clin Invest. 2004;34:392-401

2. Boilard E, Nigrovic PA, Larabee K, Watts GFM, Coblyn JS, Weinblatt ME, et al. Platelets amplify inflammation in arthritis via collagen dependent microparticle production. Science. 2010; 327(5965): 580-3 3. Thery C, Ostrowski M, Segura E. Membrane vesicles as conveyors of immune responses. Nat Rev Immunol. 2009; 9:581-93

4. del Conde I, Shrimpton CN, Thiagarajan P, Lopez JA. Tissue factor-bearing microvesicles arise from lipid rafts and fuse with activated platelets to initiate coagulation. Blood. 2005; 106:1604-11

5. Orozco AF, Lewis DE. Flow cytometric analysis of circulating microparticles in plasma. Cytometry. 2010; 77A (6):502-14

6. Nieuwland R, Sturk A. Why do cells release vesicles?. Thromb Res. 2010 Feb; 125: S49-51

7. Hunter MP, Ismail $\mathrm{N}$, Zhang $\mathrm{X}$, Aguda BD, Lee EJ, $\mathrm{Yu}$ L, et al. Detection of microRNA expression in human 
peripheral blood microvesicles. PLoS One. 2008; 3:e3694 8. Jonas R, Nilsson A, Balaj L, Hulleman E, van Rijn S, Pegtel DM, et al. Blood platelets contain tumor-derived RNA biomarkers. Blood. 2011; 118: 3680-3

9. van der Pol E, Boing AN, Harrison P, Sturk A, Nieuwland R. Classification, functions, and clinical relevance of extracellular vesicles. Pharmacol Rev 2012; 64(3): 676-705

10. Shantsila E, Kamphuisen PW, Lip GY. Circulating microparticles in cardiovascular disease: implications for atherogenesis and atherothrombosis. J Thromb Haemost 2010; 8:2358-68

11. Sprague DL, Elzey BD, Crist SA, Waldschmidt TJ, Jensen RJ, Ratliff TL. Platelet-mediated modulation of adaptive immunity: unique delivery of CD154 signal by platelet-derived membrane vesicles. Blood. 2008; 111: 5028-36

12. Simak J, Gelderman MP. Cell membrane microparticles in blood and blood products: potentially pathogenic agents and diagnostic markers. Transfus Med Rev 2006; 20:1-26

13. Prokopi M, Pula G, Mayr U, Devue C, Gallagher J, Xiao Q, et al. Proteomic analysis reveals presence of platelet microparticles in endothelial progenitor cell cultures. Blood. 2009; 114: 723-32

14. Al-Nedawi K, Meehan B, Rak J. Microvesicles: messengers and mediators of tumor progression. Cell Cycle. 2009; 8: 2014-18

15. Burnier L, Fontana P, Kwak BR, Angelillo-Scherrer A. Cell derived microparticles in haemostasis and vascular medicine. Thromb Haemost. 2009; 101:439-51

16. Wolf $\mathrm{P}$. The nature and significance of platelet products in human plasma. Br J Haematol. 1967; 13: 26988

17. Horstman LL, Ahn YS. Platelet microparticles: a wide-angle perspective. Crit Rev Oncol Hematol 1999; 30: 111-42

18. Dignat George F. Microparticles in vascular diseases. Thromb Res 2008; 122; Suppl 1, S55-9

19. Ye R, Ye C, Huang Y, Liu L, Wang S. Circulating tissue factor positive microparticles in patients with acute recurrent deep venous thrombosis. 2012; 130:253-8

20. Freyssinet JM, Toti F. Formation of procoagulant microparticles and properties. Thromb Res. 2010;125(Suppl 1): S46-8

21. Puddu P, Puddu GM, Cravero E, Muscari S, Muscari A. The involvement of circulating microparticles in inflammation, coagulation and cardiovascular diseases. Can J Cardiol. 2010; 26(4): e140-e145

22. Flaumenhaft R, Dilks JR, Richardson, Alden E, Patel-Hett SR, Battinelli E, et al. Megakaryocyte-derived microparticles: direct visualization and distinction from platelet-derived microparticles. Blood. 2009; 113:1112-21 23. Dasgupta SK, Le A, Chavakis, Rumbaut RE, Thiagarajan P. Developmental Endothelial Locus-1 (Del-1) mediates clearance of platelet microparticles by the Endotheli- um. Circulation. 2012; 125 (13): 1664-72

24. Shantsila E, Kamphuisen PW, Lip GY. Circulating microparticles in cardiovascular disease: implications for atherogenesis and atherothrombosis. J Thromb Haemost. 2010; 8(11):2358-68

25. Falanga A, Tartari CJ, Marchetti M. Microparticles in tumor progression. Thromb Res 2012; 129; Suppl 1, S132-6

26. Rak J. Microparticles in cancer. Semin Thromb Hemost. 2010; 36:888-906

27. Varon D, Hayon Y, Dashevsky O, Shai E. Involvment of platelet derived microparticles in tumor metastasis and tissue regeneration. Thromb Res 2012; 130: S98-9

28. Castaman G, Yu-Feng L, Rodeghiero F. A bleeding disorder characterized by isolated deficiency of platelet microvesicle generation. Lancet 1996; 347:700-1

29. Castaman G, Yu-Feng L, Battistin E. Characterization of a novel bleeding disorder with isolated prolonged bleeding time and deficiency of platelet microvesicle generation. Br J Haematol 1997; 96:458-63

30. Zwaal RF, Comfurius P, Bevers EM. Scott syndrome, a bleeding disorder caused by defective scrambling of membrane phospholipids. Biochim Biophys Acta 2004; 1636:119-28

31. Ahn YS. Cell-derived microparticles:'Miniature envoys with many faces'. J Thromb Hemost 2005; 3:884-7

32. Rank A, Nieuwland R, Delker R, Kohler A, Toth B, Pihusch V, et al. Cellular origin of platelet-derived microparticles in vivo. Thromb Res. 2010; 126: e255-e259

33. Lechner D, Weltermann A. Circulating tissue factorexposing microparticles. Thromb Res. 2008; 122 (Suppl.1):S47-54

34. Sinauridze EI, Kireev DA, Popenko NY, Pichugin AV, Panteleev MA, Krymskaya OV, et al. Platelet microparticle membranes have 50- to 100-fold higher specific procoagulant activity than activated platelets. Thromb Haemost 2007; 97(3):425-34

35. Jy W, Horstman LL, Jimenez JJ, Ahn YS, Biró E, Nieuwland R, et al. Measuring circulating cell-derived microparticles. J Thromb Haemost 2004; 2:1842-3

36. Ravichandran KS, Lorenz U. Engulfment of apoptotic cells: signals for a good meal. Nat Rev Immunol. 2007 Dec; 7(12):964-74

37. Castellana D, Totti F, Freyssinet JM. Membrane microvesicles: macromessengers in cancer disease and progression. Thromb Res. 2010; 125 (Suppl 2):S84-8

38. Campello E, Spiezia L, Radu CM, Bulato C, Castelli M, Gavasso S, et al. Endothelial, platelet, and tissue factor-bearing microparticles in cancer patients with and without venous thromboembolism. Thromb Res. 2011; 127(5):473-7

39. Basavaraj MG, Olsen JO, Osterud B, Hansen JB. Differential ability of tissue factor antibody clones on detection of tissue factor in blood cells and microparticles. Thromb Res. 2012; 130:538- 
40. Key NS. Analysis of tissue factor positive microparticles. Thromb Res. 2010; 125:S42-5

41. Ruf W. Tissue factor and cancer. Thromb Res. 2012; S84-7

42. Zwicker JI. Predictive value of tissue factor bearing microparticles in cancer associated thrombosis. Thromb Res.2010; 125(Suppl.2):S89-91

43. Chitlur M, Massicotte MP. The perfect measure of hemostasis: a quest for the holy grail. Thromb Res. 2010; 125(6): 481-2

44. Favaloroa EJ, Lippi G. Coagulation update: what's new in hemostasis testing? Thromb Res. 2011; 127; Suppl. 2 :S13-S6

45. Siljander PRM. Platelet-derived microparticles - an updated perspective. Thromb Res. 2011; 127:S30-3

46. Lawrie AS, Albanyan A, Cardigan RA, Mackie IJ, Harrison P. Microparticle sizing by dynamic light scattering in fresh-frozen plasma. Vox Sang.2009; 96(3):206-12

47. Yuana Y, Oosterkamp TH, Bahatyrova S...Atomic force microscopy: a novel approach to the detection of nano-sized blood microparticles. J Thromb Haemost. 2010; 8(2):315-23

48. Gross PL, Vaezzadeh N. Tissue factor microparticles and haemophilia. Thromb Res.2010; 125:S67-9

49. Dignat-George F, Feyssinet JM, Key NS. Centrifugation is a crucial step impacting microparticle measurement. Platelets. 2009 ; 20(3):225-6

50. Ayers L, Kohler M, Harrison P, Sargent I, Dragovic R, Schaap M, et al. Measurement of circulating cell-derived microparticles by flow cytometry: Sources of variability within the assay. Thromb Res 2011; 127:370-7
51. Lacroix R, Judicone C, Poncelet P, Robert S, Arnaud $\mathrm{L}$, Sampol J et al. Impact of pre-analytical parameters on the measurement of circulating microparticles: towards standardization of protocol. J Thromb Haemost 2012; 10:437-46

52. Robert S, Poncelet P, Lacroix R, Arnaud L, Giraudo L, Hauchard A, et al. Standardization of platelet-derived microparticle counting using calibrated beads and a Cytomics FC500 routine flow cytometer: a first step towards multicenter studies? J Thromb Haemost. 2009; 7(1):190-7

53. Trummer A, De Rop C, Tiede A, Ganser A, Eisert R. Isotype controls in phenotyping and quantification of microparticles: A major source of error and how to evade it. Thromb Res 2008; 122:691-700

54. György B, Módos K, Pállinger E, Pálóczi K, Pásztói M, Misják P et al. Detection and isolation of cell-derived microparticles are compromised by protein complexes resulting from shared biophysical parameters. Blood. 2011; 117(4):e39-48

55. Williams JC, Mackman N. MPs or ICs? Blood. 2011; 117: $1101-2$

56. Mobarrez F, Antovic J, Egberg N, Hansson M, Jorneskog G, Hultenby $\mathrm{K}$ et al. A multicolor flow cytometric assay for measurement of platelet-derived microparticles. Thromb Res 2010; 125:e110-6

57. Hind E, Heugh S, Ansa-Addo EA, Antwi-Baffour S, Lange S, Inal J. Red cell PMVs, plasma membrane-derived vesicles calling out for standards. Biochem Biophys Res Commun 2010; 399: 465-9 